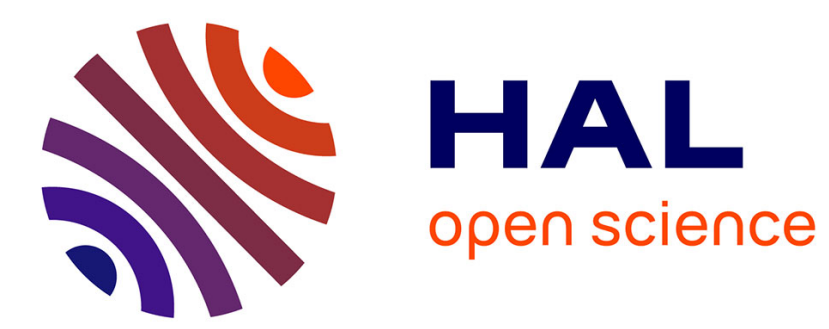

\title{
Prevalence of levamisole and aminorex in patients tested positive for cocaine in a French University Hospital
}

\author{
Céline Eiden, Hélène Peyrière, Caroline Diot, Olivier Mathieu
}

\section{To cite this version:}

Céline Eiden, Hélène Peyrière, Caroline Diot, Olivier Mathieu. Prevalence of levamisole and aminorex in patients tested positive for cocaine in a French University Hospital. Clinical Toxicology, 2015, 53

(7), pp.604-608. hal-01987718

\section{HAL Id: hal-01987718 \\ https://hal.science/hal-01987718}

Submitted on 21 Jan 2019

HAL is a multi-disciplinary open access archive for the deposit and dissemination of scientific research documents, whether they are published or not. The documents may come from teaching and research institutions in France or abroad, or from public or private research centers.
L'archive ouverte pluridisciplinaire HAL, est destinée au dépôt et à la diffusion de documents scientifiques de niveau recherche, publiés ou non, émanant des établissements d'enseignement et de recherche français ou étrangers, des laboratoires publics ou privés. 


\title{
Prevalence of levamisole and aminorex in patients tested positive for cocaine in a French University Hospital
}

\author{
CÉLINE EIDEN, ${ }^{1}$ HÉLÈNE PEYRIÈRE, ${ }^{1}$ CAROLINE DIOT, ${ }^{1}$ and OLIVIER MATHIEU ${ }^{2}$ \\ ${ }^{1}$ Department of Medical Pharmacology and Toxicology, Addictovigilance centre, Montpellier University Hospital, Montpellier University \\ ${ }^{2}$ Department of Medical Pharmacology and Toxicology, Toxicology Laboratory, Montpellier University Hospital, Montpellier University
}

Context. The prevalence of levamisole in urine samples of subjects positive for cocaine in the US was estimated at $78 \%(95 \%$ confidence interval or CI: $73 \%-83 \%$ ). However, levamisole was not quantified, and at the time of this report, aminorex was not known to be a possible metabolite of levamisole in human. Moreover no data are available in Europe. Objective. The aim of this study was to determine the prevalence and concentration of levamisole and aminorex in positive cocaine urine toxicology tests, and in serum samples of cocainepositive subjects driving under the influence of drugs or forensic autopsies. Materials and methods. Consecutive urine toxicology samples tested positive for cocaine by immunoassay (EMIT, Siemens) from April to May 2014 at the toxicology laboratory of a French University Hospital, and blood samples of cocaine-positive subjects driving under the influence of drugs or forensic autopsies from April to December 2014 were analyzed by liquid chromatography-tandem mass spectrometry or LC-MS/MS (3200 QTrap, AB Sciex) to detect and quantify the presence of levamisole and aminorex. Results. Forty-two urine samples tested positive for cocaine in 39 patients (79.5\% males) with a median age of 43 [range: $20-51$ ] years. Toxicological analyses were mainly required by addictions care centers $(n=17 ; 40 \%)$ in the context of the routine management of addict patients. Cocaine concentrations were above the limit of quantification for 33 patients, with a median value of 228 [0-645,000] ng/ml. Levamisole was detected in 32 urine samples (76\%) (median concentration: 1,430 ng/ml, range: 30-258,000). Aminorex was never detected. During the study period, levamisole was detected in $87.5 \%$ of cocaine-positive blood samples of the subjects driving under the influence of drugs or forensic autopsies. Discussion. In this prospective study, the prevalence of levamisole in cocaine-positive samples was $76 \%$. Over this period, although clinical complications related to cocaine use were reported (agitation, road accident, and cardiac arrest), no complication specifically related to levamisole or aminorex was reported. Conclusion. Our results show a high prevalence of levamisole in samples of subjects positive for cocaine, close to the prevalence found in the US. This high prevalence raises issues with respect to well-identified health risks associated with regular consumption of levamisole.

Keywords Levamisole; Cocaine; Aminorex; Concentrations; Prevalence; Clinical setting

\section{Introduction}

Levamisole, a medication with anthelmintic and immunomodulatory properties, is widely reported as a cocaine adulterant. The main complications related to medical use of levamisole are leukopenia, agranulocytosis, thrombocytopenia, vasculitis, leukoencephalopathy, arthritis, digestive symptoms, and syndrome of inappropriate antidiuretic hormone secretion. ${ }^{1}$ However, in the context of cocaine adulterated with levamisole, the complications described in cocaine users are neutropenia, cutaneous complications, arthralgias, thrombocytopenia, hyponatremia, and related deaths. ${ }^{1}$ Indeed, a post-mortem case of coronary artery disease with inflammatory eosinophilia following the abuse of

Address correspondence to Dr. Céline Eiden, Service de Pharmacologie Médicale et Toxicologie, Hôpital Lapeyronie, 191 avenue du Doyen Gaston Giraud, 34295 Montpellier Cedex 5, France. Tel: 33-4-67-33-05-40. Fax: 33-4-67-33-67-51. E-mail: c-eiden@chu-montpellier.fr cocaine adulterated with levamisole has been described with detection of levamisole in urine and pericardial fluid. ${ }^{2}$

The amphetamine-like substance aminorex (anorectic stimulant) has been found to be a metabolite of levamisole, firstly in horse, and more recently in human. As aminorex is known to induce idiopathic pulmonary hypertension (IPH), the question was to know whether the amount of aminorex formed from levamisole is large enough to induce $\mathrm{IPH}^{3}$

In 2010, Buchanan et al. estimated at 78\% (95\% confidence interval [CI]: $73 \%-83 \%$ ) the prevalence of levamisole in urine toxicology screens positive for cocaine in a 500-bed public safety-net hospital. ${ }^{4}$ However, levamisole was not quantified, and at the time of the study, aminorex was not known to be a possible metabolite of levamisole in human. ${ }^{4}$ Pharmacokinetic studies on levamisole metabolism in human were performed after oral administration of 47, 58, and 100 $\mathrm{mg}$ of levamisole in healthy volunteers., They indicated that maximum concentrations of aminorex of about $40 \mathrm{ng} / \mathrm{ml}$ can be expected in urine after oral levamisole. Moreover, serum samples from 106 subjects positive for cocaine and 
driving under the influence of drugs were retrospectively analyzed between 2011 and 2012. ${ }^{6}$ Levamisole was quantified in $42.5 \%$ of cases and concentrations ranged from 2.2 to 224 (mean value: 45.8 ; therapeutic range: $700-1,500$ ) $\mathrm{ng} / \mathrm{ml}$. Aminorex was positive in 12 cases $(11.3 \%)$ and the concentrations were always below the limit of quantification (LOQ). ${ }^{6}$

As in North America, levamisole is becoming the most common cocaine adulterant in European countries. However, to date, no data are available concerning the prevalence of levamisole and aminorex and their quantification in urine.

The aim of this prospective single-center study conducted at the University Hospital of Montpellier was to determine the prevalence of levamisole and aminorex in urine samples tested positive for cocaine in the clinical setting management. In addition, blood samples of cocaine-positive subjects driving under the influence of drugs or forensic autopsies from April to December 2014 were also analyzed.

\section{Materials and methods}

\section{Urine samples}

Consecutive urine toxicology samples tested positive for cocaine by immunoassay (EMIT, Siemens) from April to May 2014 at the toxicology laboratory of the University Hospital of Montpellier were analyzed by liquid chromatography-tandem mass spectrometry (LC-MS/MS) (3200 QTrap, AB Sciex) to detect and quantify levamisole (LOQ: $30 \mathrm{ng} / \mathrm{ml}$ ) and aminorex (LOQ: $30 \mathrm{ng} / \mathrm{ml}$ ).

Levamisole and aminorex were quantified using a toxicological screening of illicit drugs (except natural cannabinoids). Briefly, $100 \mu \mathrm{l}$ of urine was diluted with $100 \mu \mathrm{l}$ of acetonitrile of LC-MS/MS grade and $50 \mu \mathrm{l}$ of benzoylecgonine (BZE) D3 $(100 \mathrm{ng} / \mathrm{ml})$ used as internal standard. After centrifugation (3000 rpm, 10 minutes), the supernatant was diluted with the mobile phase (1:4) before injection. The chromatographic separation was performed on an Allure PFP propyl column $(5 \mu \mathrm{m}, 50 \times 2.1 \mathrm{~mm})$ from Restek (Lisses, France). The chromatographic conditions used a mixture of acetonitrile and formate buffer $(\mathrm{pH}, 3.2)$ with a gradient from 10/90 to $90 / 10$ for $17.5 \mathrm{mn}$. The couples of MS/MS $\mathrm{m} / \mathrm{z}$ transitions used were $(205 / 91.0 ; 205 / 178)$ and $(163 / 120$; 163/103) for levamisole and aminorex, respectively.

Quantification of cocaine and its metabolites BZE and ecgonine methyl ester (EME) were performed by LC-MS/ MS using the same procedure.

Natural cannabinoids were detected by immunoassay (EMIT, Siemens) and ethanol with an enzymatic method (Siemens).

\section{Blood samples}

Blood samples positive for cocaine from April to December 2014 were included. The determination of levamisole, aminorex, cocaine, its main metabolites (ecgonine methyl ester, benzoylecgonine, and cocaethylene), and cannabinoids, and the full toxicological screening were performed in accordance with our laboratory usual procedure using LCMS/MS and gas chromatography or GC-MS strategies. The determination of levamisole and aminorex was performed as follows. After a simple precipitation step with acetonitrile (1:4), the supernatant was dried and then diluted with mobile phase before injection. LC-MS/MS analysis is the same as that for urine samples. LOQ for levamisole and aminorex was $1 \mathrm{ng} / \mathrm{ml}$.

\section{Demographic and clinical data}

Demographic (gender and age) and clinical characteristics (data on cocaine abuse and opiate maintenance therapy), and pattern of toxicological analysis of patients were collected on the toxicological analysis request and completed with the computerized patient record.

In France, the Addictovigilance Network collects cases of dependence or misuse leading to severe complications. All health professionals have the obligation to spontaneously notify to the addictovigilance center of their French administrative region all cases of abuse or misuse they observe. ${ }^{8}$

\section{Results}

\section{Urine samples}

Five hundred forty samples were collected from April to May 2014 in the context of psychoactive substances screening, including cocaine. Forty-two samples $(7.8 \%)$ were tested positive for cocaine by immunoassay in 39 patients ( 31 men and 8 women) with a median age of 43 [range: 20-51] years. Demographic and clinical characteristics are summarized in Table 1. Hospital departments which requested analyses were addictions care center $(N=17 ; 40 \%)$, emergency department $(N=7 ; 17 \%)$, penitentiary center $(N=7 ; 17 \%)$, addictology in- and outpatients department $(N=6 ; 14 \%)$, anesthesiology department $(N=2 ; 5 \%)$, psychiatric department $(N=2 ; 5 \%)$, and obstetric department $(N=1 ; 2 \%)$.

Analyses were conducted mainly in the context of the routine management of addict patients ( $76 \%$ of cases) or agitation in the context of substance abuse (9\%). Half of the patients received opiate maintenance therapy. Cocaine abuse was documented (data available on the analysis request or/and on the computerized patient record) for $40 \%$ of patients. In the remaining patients it was not recorded by the physicians.

Of the 42 samples, one was false positive. Urinary concentrations of cocaine, EME, BZE, levamisole, and aminorex are summarized in Table 2. Levamisole was detected in $32(76 \%)$ of the 42 samples. Aminorex was never detected. Cocaine urinary concentrations were above the LOQ for 33 patients. Other substances found in the samples were opioids (methadone, 16 patients; buprenorphine, 9 patients; morphine, 8 patients; and tramadol, 3 patients), ethanol (4 patients), cocaethylene (14 patients), tetrahydrocannabinol (THC) 27 patients, and amphetamines (6 patients) (doubtful result confirmed by LC-MS/MS in 1 case), other substances as methylphenidate (1 patient) and JWH-122 (a synthetic cannabimimetic, 1 patient). 
Table 1. Demographic and clinical characteristics for cocaine-positive urine samples.

\begin{tabular}{lc}
\hline & $\begin{array}{c}\text { Patients } \\
(n=39)\end{array}$ \\
\hline Gender & $31(80 \%)$ \\
Male & \\
Age (years) (mean \pm SD) & $43 \pm 8$ years \\
Cocaine & \\
Documented abuse & $16(41 \%)$ \\
$\quad$ IV route* & 4 \\
$\quad$ Nasal route & 2 \\
$\quad$ Inhaled & 1 \\
$\quad$ Not documented & 11 \\
History of cocaine withdrawal & $3(8 \%)$ \\
Opiate maintenance therapy (unknown 10 patients) & $16(41 \%)$ \\
Methadone & $10(62 \%)$ \\
Buprenorphine & $6(38 \%)$ \\
OMT withdraw & 5 \\
No OMT & 8 \\
Pattern of toxicological analysis request & $(n=42)$ \\
Addiction protocol support & $32(76 \%)$ \\
Agitation & 3 \\
Road accident & 2 \\
Sepsis on cocaine injection & 1 \\
Brawl & 1 \\
Ketoacidosis coma on cocaine & 1 \\
Cardiac arrest (death) & 1 \\
Hydramnios & 1 \\
\hline
\end{tabular}

$\mathrm{SD}$, standard deviation.

${ }^{*}$ One patient used several routes.

Although clinical complications related to cocaine use were reported (agitation, road accident, and cardiac arrest), no complication specifically related to levamisole or aminorex was reported to the addictovigilance center.

\section{Blood samples}

During the study period, levamisole was quantified in 7 of the 8 cocaine-positive plasma samples $(87.5 \%)$ of the driving under the influence of drugs. Concentrations ranged from 2.6 to 112 (mean value: 58.5 ) ng/ml. Aminorex was positive in only 3 cases $(37.5 \%), 2$ cases were below the LOQs of $1 \mathrm{ng} / \mathrm{ml}$, and one case was measured at $2.4 \mathrm{ng} / \mathrm{ml}$.

During the same period, among the 7 cocaine-positive post-mortem blood samples from forensic autopsies (results detailed in Table 3), levamisole was quantified in 6 cases $(87.5 \%)$. Concentrations ranged from 1 to 125 (mean value: 38.4 ) $\mathrm{ng} / \mathrm{ml}$. Aminorex was positive in only 1 case (below the LOQs of $1 \mathrm{ng} / \mathrm{ml}$ ) (Table 3 ).

\section{Discussion}

\section{Levamisole}

In this prospective study, levamisole was detected in $76 \%$ of cocaine-positive urine samples. This is comparable to the value found in the study of Buchanan et al. performed in the USA where $78 \%$ (95\% CI: 73\%-83\%) of cocaine-positive samples contained levamisole. However, no quantification of levamisole in the context of clinical setting was documented. A post-mortem study carried out in the UK between April 2005 and April 2006, on 2321 coroners' samples, found that among 101 urine samples positive for cocaine, 14 were positive for levamisole, with concentrations of levamisole ranging from $<5$ to $1,589 \mathrm{ng} / \mathrm{ml} .{ }^{9}$ In another study carried out in 2011-2012, levamisole was detected in the urine of 11 of 12 cocaine-positive subjects driving under the influence of drugs with concentrations ranging from $3.7 \mathrm{ng} / \mathrm{ml}$ to $500 \mathrm{ng} / \mathrm{ml}$. ${ }^{6}$

In our study, we found a wide variability of urinary concentrations for cocaine (interquartile range [IQR]: 31-3,555 $\mathrm{ng} / \mathrm{ml}$ ), EME, BZE, and levamisole (IQR: 33-2,860 ng/ml). However, the delay between cocaine intake and urine collection, route of administration, underlying health, age, coadministration of other substances, duration of use, amount of cocaine consumed, and percentage of levamisole in cocaine powder could alter the concentrations of cocaine, its metabolites, and levamisole. The urine concentrations of cocaine and its metabolites measured in our study seem consistent with a retrospective study performed in Chicago in $2000 .{ }^{10}$ The authors examined the levels of cocaine and its major metabolites in plasma and urine from 29 patients randomly selected in an emergency department. In urine, the concentration ranges were $4-40,130 \mathrm{ng} / \mathrm{ml}$ for cocaine, 36-6,60,550 ng/ml for EME, and 106-3,361,000 $\mathrm{ng} / \mathrm{ml}$ for BZE. ${ }^{10}$

Levamisole concentrations ranged from 1 to $125 \mathrm{ng} / \mathrm{ml}$ in blood samples from both subjects driving under the influence of drugs and forensic autopsies. This range is close to the values found by Hess et al. $(2.2-224 \mathrm{ng} / \mathrm{ml})$ with the same way of recruitment. ${ }^{6}$

\section{Aminorex}

We have never detected aminorex in urine. In the pharmacokinetic study of Hess et al., after an oral dose of $100 \mathrm{mg}$ of levamisole, aminorex concentrations in urine reached the maximum of $45 \mathrm{ng} / \mathrm{ml}$ after $7 \mathrm{~h}$, and stayed $>30 \mathrm{ng} / \mathrm{ml}$ for up to $30 \mathrm{~h}$ after ingestion. It could be detected up to $54 \mathrm{~h}$ after ingestion, but concentrations never exceeded the LOQ

Table 2. Urinary concentrations of cocaine and its metabolites (BZE and EME) and levamisole in the 42 samples positive for cocaine in immunoassay.

\begin{tabular}{|c|c|c|c|c|c|}
\hline $\begin{array}{l}\text { Concentration } \\
(\mathrm{ng} / \mathrm{ml})\end{array}$ & $\begin{array}{c}\mathrm{COC} \\
N=33\end{array}$ & $\begin{array}{c}\text { BZE } \\
N=41\end{array}$ & $\begin{array}{c}\text { EME } \\
N=31\end{array}$ & $\begin{array}{c}\text { LEV } \\
N=32\end{array}$ & $\begin{array}{l}\text { AMI } \\
N=0\end{array}$ \\
\hline Mean & 42,322 & 74,773 & 31,724 & 19,016 & - \\
\hline Median & 227 & 15,600 & 1,435 & 390 & - \\
\hline Quartile 25\% & 31 & 962 & 20 & 33 & - \\
\hline Quartile 75\% & 3,555 & 68,600 & 13,750 & 2,860 & - \\
\hline Min-Max & $0-6,45,000$ & $0-6,27,000$ & $0-4,27,000$ & $0-2,58,000$ & - \\
\hline
\end{tabular}

COC, cocaine; EME, ecgonine methyl ester; BZE, benzoylecgonine; LEV, levamisole; AMI, aminorex. 
Table 3. Determination of levamisole and aminorex in cocaine-positive whole blood cases from forensic autopsies (ng/ml).

\begin{tabular}{|c|c|c|c|c|c|c|c|c|c|}
\hline Cases & Age & Gender & Post mortem material & Death diagnosis & \multicolumn{5}{|c|}{ Whole blood concentration ( $\mathrm{ng} / \mathrm{mL})$} \\
\hline 1 & 40 & M & Peripheral blood & Myocardial infarction & 268 & 1630 & 1750 & 1.4 & ND \\
\hline 3 & 23 & $\mathrm{~F}$ & Peripheral blood & Defenestration & 1 & 437 & 248 & ND & ND \\
\hline 4 & 38 & M & clot & Asphyxic syndrome related to pulmonary edema & 2.4 & 255 & 29 & 8.5 & ND \\
\hline 5 & 39 & M & blood & hemorrhagic shock (gunshot wound) & 1.7 & 67 & 19 & 2.7 & ND \\
\hline
\end{tabular}

$\mathrm{ND}$, none detected; COC, cocaine; EME, ecgonine methyl ester; BZE, benzoylecgonine; LEV, levamisole; AMI, aminorex.

$(0.34 \mathrm{ng} / \mathrm{ml}) .{ }^{11}$ In another publication, after the administration of $47 \mathrm{mg}$ (health female volunteer) and $58 \mathrm{mg}$ (health male volunteer) of levamisole by oral route, aminorex concentrations in urine were $22.5-38.1 \mathrm{ng} / \mathrm{ml} 3 \mathrm{~h}$ after the intake and $20.1-43.6 \mathrm{ng} / \mathrm{ml} 6 \mathrm{~h}$ after ingestion. ${ }^{5}$ These studies indicate that a peak concentration of aminorex of about $40 \mathrm{ng} / \mathrm{ml}$ can be expected in urine after oral levamisole. It is not possible to estimate the expected concentration of aminorex after the use of an unknown amount of cocaine containing an unknown amount of levamisole. Moreover, no data are available concerning aminorex concentrations after intravenous, nasal, or inhaled levamisole administration. In the horse, a chemical reaction for the conversion of levamisole to aminorex was proposed involving a protonation forming an intermediate which can undergo an alkylation leading to a loss of thiirane to yield aminorex. ${ }^{12,13}$ The reaction needs acidic condition.

In our study, aminorex was not detected in urine despite the quantification of levamisole concentrations; however, it was detected in whole blood samples, one forensic autopsy cocaine-positive case, and in three plasma samples of people driving under the influence of drugs but at very low concentrations $(<5 \mathrm{ng} / \mathrm{ml})$. These results in blood are qualitatively and quantitatively in agreement with recently published data. $^{6}$

One hypothesis could be related to the polymorphism of the enzyme responsible for levamisole metabolism, as suggested by the study of Bertol et al. ${ }^{5}$ They found that only $4 / 12$ forensic urine samples from cocaine users were positive for both levamisole and aminorex. ${ }^{5}$ For the other 8 samples, the authors speculated that these samples were not adulterated or that one of the enzymes responsible for the conversion of levamisole to aminorex is polymorphic. No data are available concerning the cocaine route of administration.

In our study, one explanation for the non-detection of aminorex in urine could be the route of administration of cocaine. In the few studies investigating the pharmacokinetic of levamisole, it was absorbed orally. ${ }^{5,6}$ The subjects who abuse cocaine take it intravenously or nasally, two routes of administration that shunt the stomach. In the study of Gutierrez et al., the author speculated that the first step of the metabolism of levamisole to aminorex is a triple protonation. ${ }^{12,13}$ The Presence of aminorex may be only the consequence of the absorption of the aminorex formed in the stomach, rather than the result of the hepatic metabolism of levamisole. Finally, despite very high levels of levamisole, aminorex in urine was below the LOQ and the level of detection. Unfortunately, we were not able to link blood and urine data because of the way of recruitment and the lack of urine in autopsy cases. Based on the median, a four- to ten-fold factor of the levamisole levels was observed between both matrices, and up to a 1,000-fold factor if extremes are considered. Such a factor is probable for aminorex in agreement with our data and those of Hess et al. ${ }^{6}$ Both low formation with extra-enteral routes and urinary concentration factor unable to overpass our LOQ may explain the lack of aminorex detection in urine.

\section{Conclusion}

In this prospective study, levamisole was detected in more than three of four cocaine-positive samples, even if metabolite aminorex was never detected in urine. Nevertheless, over this period, although clinical complications related to cocaine use were observed, no complication specifically related to levamisole or aminorex was reported. In view of the high prevalence of levamisole concentrations, it is important that health authorities assess more accurately the risks and health consequences of long-term consumption of adulterated levamisole. In addition, users of cocaine should be informed of these risks.

\section{Declaration of interest}

The authors report no declarations of interest. The authors alone are responsible for the content and writing of the paper.

\section{References}

1. Larocque A, Hoffman RS. Levamisole in cocaine: unexpected news from an old acquaintance. Clin Toxicol (Phila) 2012; 50:231-241.

2. Michaud K, Grabherr S, Shiferaw K, Doenz F, Augsburger M, Mangin P. Acute coronary syndrome after levamisole-adultered cocaine abuse. J Forensic Leg Med 2014; 21:48-52.

3. Karch SB, Mari F, Bartolini V, Bertol E. Aminorex poisoning in cocaine abusers. Int J Cardiol 2012; 158:344-346. 
4. Buchanan JA, Heard K, Burbach C, Wilson ML, Dart R. Prevalence of levamisole in urine toxicology screens positive for cocaine in an inner-city hospital. JAMA 2011; 305:1657-1658.

5. Bertol E, Mari F, Milia MG, Politi L, Furlanetto S, Karch SB. Determination of aminorex in human urine samples by GC-MS after use of levamisole. J Pharm Biomed Anal 2011; 55:1186-1189.

6. Hess C, Ritke N, Sydow K, Mehling LM, Ruehs H, Madea B, Musshoff F. Determination of levamisole, aminorex, and pemoline in plasma by means of liquid chromatography-mass spectrometry and application to a pharmacokinetic study of levamisole. Drug Test Anal 2014; 6:1049-1054

7. Eiden C, Diot C, Mathieu O, Mallaret M, Peyrière H. LevamisoleAdulterated Cocaine: What about in European Countries? J Psychoactive Drugs 2014; 46:389-392.

8. Baumevieille M, Miremont G, Haramburu F, Maurain C, Bégaud B. The French system of evaluation of dependence: establishment in a legal system. Thérapie 2011; 56:15-22.
9. Morley SR, Hall JC, Forrest ARW, Galloway JH. Levamisole as a contaminat of illicit cocaine. J Clandestine Lab Invest Chemists Assoc 2006; 16:6-11.

10. Williams RH, Maggiore JA, Shah SM, Erickson TB, Negrusz A. Cocaine and its major metabolites in plasma and urine samples from patients in an urban emergency medicine setting. J Anal Toxicol 2000; 24:478-481.

11. Hess C, Ritke N, Broecker S, Madea B, Musshoff F. Metabolism of levamisole and kinetics of levamisole and aminorex in urine by means of LC-QTOF-HRMS and LC-QqQ-MS. Anal Bioanal Chem 2013; 405:4077-4088.

12. Ho EN, Leung DK, Leung GN, Wan TS, Wong AS, Wong CH, et al. Aminorex and rexamino as metabolites of levamisole in the horse. Anal Chim Acta 2009; 638:58-68.

13. Gutierrez J, Eisenberg RL, Koval NJ, Armstrong ER, Tharappel J, Hughes CG, Tobin T. Pemoline and tetramisole 'positives' in english racehorses following levamisole administration. Ir Vet J 2010; 63:498-500. 